\title{
Succession Financing in Family Firms
}

\author{
Christian Koropp ${ }^{+}$ \\ Institute of Technology Management, University of St. Gallen, \\ Dufourstrasse 40a, 9000 St. Gallen, Switzerland \\ Tel: +41 (71) 224-7200 \\ christian.koropp@unisg.ch \\ Dietmar Grichnik \\ Institute of Technology Management, University of St. Gallen, \\ Dufourstrasse 40a, 9000 St. Gallen, Switzerland
}

André F. Gygax

Department of Finance, Faculty of Business \& Economics, University of Melbourne

Victoria 3010, Australia

† Corresponding author.

Keywords:

Family Firms, Succession, Decision Making, Debt Financing

JEL Classification: G32, L26

Abstract:

Business succession is one of the primary management challenges for family firms. However, many family firms fail at this task because of financial issues. Although a vast number of studies have investigated the succession process, research thus far has failed to determine how and why family firms select particular forms of financing for succession-related expenditures. Accordingly, this study conceptually and empirically investigates succession financing. We introduce a conceptual framework that investigates the reasons behind an owner-manager's intent to use debt for succession financing. 
Specifically, our model accounts for general and succession-related personal factors. However, we also include a set of firm-specific financing behavioral controls in our research. The empirical results are derived from a sample of 187 German family firms, and the results highlight financial knowledge, attitudes, succession experience, and succession planning as significant determinants of the ownermanagers' debt usage intentions. The implications and avenues for future research are discussed. 


\section{Succession Financing in Family Firms}

\section{Introduction}

Business succession is a critical event within the life cycle of a family firm because it affects the firm's performance, the firm's value, and, potentially, the firm's survival (e.g., Diwisch et al. 2009; Bennedsen et al. 2007). However, most family firms fail at the challenge of managing a successful business succession (e.g., Miller et al. 2003). The need for financing is a common impediment that prevents successful succession outcomes for family firms (De Massis et al. 2008). These financing needs mainly arise from transaction costs. For example, there may be taxes or compensation payments to the incumbent, other family members or heirs; additionally, realignment and restructuring costs could be incurred, which place serious constraints on the family's and firm's resources. Insufficient or inappropriate financing and financial structuring can impede succession or constrain the family firm's future growth. For these reasons, all other succession management activities (e.g., succession planning or successor qualification) become redundant if the succession-related financial requirements are not met. Accordingly, an understanding of how and why family firms employ a certain financial source for funding succession-related expenditures is essential for the management of a successful succession.

Given the prevalence of family firms worldwide (e.g., Burkart et al. 2003), negative succession effects can extend beyond the family firm, negatively impacting an economy's productivity and growth. On average, 690,000 European small- and medium-sized enterprises ${ }^{1}$ change hands each year, affecting 2.8 million jobs (European Commission 2006). Thus, a substantial body of research on family firm succession has emerged that analyzes succession from distinct perspectives. Specifically, research has investigated (1) personal factors, such as the motivations and characteristics of the predecessor and the successor (e.g., Sharma and Irving 2005) or the relationships between the predecessor, the successor, and the family (e.g., Miller et al. 2003; Morris et al. 1996); (2) succession process factors, such as succession planning (e.g., Sharma et al. 2003b); and (3) firm factors, such as board composition (Dunn 1999). Most empirical studies employ a case study approach and investigate only a limited number of family firms (e.g., Miller et al. 2003; Chittoor and Das 2007; Ibrahim et al. 2001). Moreover, although succession in family firms involves both management transition and - sometimes deferred - ownership transition, most research is exclusively focused on the management transitions (e.g., Chittoor and Das 2007; Stavrou 2003). Moreover, although additional financial demands are likely to emerge during the ownership transition process (De Massis et al. 2008), scientific research on succession financing decisions is scarce. Instead, we find several studies that have investigated the impact of succession on a firm's financial structure (e.g., Blanco-Mazagatos et al. 2007; Schulze et al. 2003) in terms of the generational differences in the respective funding

\footnotetext{
${ }^{1}$ This is not to say that family firms are fully congruent with small and medium-sized enterprises; however, most of these enterprises are, in fact, family firms.
} 
behaviors. Most of the studies in this field explore the differences in the capital structures of founder- and descendant-controlled family firms (e.g., McConaughy et al. 2001), rather than the financing decisions behind succession. As such, the important influences of financing decisions on succession outcomes and the drivers behind these decisions have generally been disregarded.

Therefore, this paper examines the succession financing decisions in family firms. Specifically, this paper draws on insights from the theory of planned behavior (Ajzen 1991), capital structure choice research (e.g., Barton and Gordon 1987; Blanco-Mazagatos et al. 2007) and succession literature (e.g., Chittoor and Das 2007; De Massis et al. 2008) to investigate the influence of personal, succession process-related, and firm factors on the owner-managers' succession financing intentions. Behavioral intentions are the most accurate predictors of future decision-making behavior (for a review, see Armitage and Conner 2001), such as debt financing decisions (Grichnik et al. 2011). Succession financing, in particular, may cause external financial demands because the owner-managers and their families usually invest most of their wealth into the business (Sharma et al. 2003a), and family firms do not possess vast internal financing capabilities (Kimhi 1997). Family firms generally prefer debt over equity financing (Gallo et al. 2004) or even equate external financial sources with debt financing (Romano et al. 2001). Because anecdotal evidence suggests that a large number of family firms rely on debt financing to orchestrate successful successions (L-Bank 2006), we specifically study the owner-manager's intention to use external debt for succession financing. This research is based on a sample of 187 German family firms that were asked to indicate which financial sources they were most likely to use for succession financing. Our data were analyzed using a set of binary logistic regression models.

This paper makes at least three primary contributions to the family firm succession and management literature. First, research has only recently begun to systemize the factors that prevent successful family firm succession, thereby stressing the importance of an appropriate financing choice for the transition process (De Massis et al. 2008). This study therefore adds to the current debate by introducing and investigating the first conceptual model of succession financing decision-making. Second, we contribute to the succession literature by investigating the process of ownership transition, which has not been a focus of past research. Most studies of family firm succession are focused on the various determinants affecting management transition (e.g., Chittoor and Das 2007; Stavrou 2003). For this reason, we also contribute to the literature because our model simultaneously accounts for the effects of personal, process and firm factors on financing ownership transitions. Third, existing studies on family firm financing generally consider financial decision making to be primarily driven by firm factors and theorize that any differences between the decisions of family and non-family firms are a result of personal factors (e.g., Gallo et al. 2004; López-Gracia and Sánchez-Andújar 2007). We contribute to this stream of literature by showing how non-economic variables, such as experience, can influence the economic decision-making behavior in family firms. Therefore, our results add to the 
knowledge-based view of the succession process (Cabrera-Suárez et al. 2001) because we investigate specific forms of knowledge and experience and their influence on an important part of the succession process.

The paper proceeds as follows: The next section reviews the relevant succession, psychology and finance literature to develop the hypotheses for our conceptual model. The methodology is explained in the third section and includes sample selection and the measurements used. Next, the empirical results of the logistic regression analyses are presented. Finally, the paper concludes with a discussion of the key findings, followed by the limitations, the avenues for future research and the concluding remarks.

\section{Theory and Hypotheses}

\subsection{On the Desirability of Debt Financing Within Family Firm Succession: An Overarching Framework}

This section first briefly defines the common elements of the family firm succession process and then provides a theoretical development regarding the desirability of debt financing within the succession process.

The literature highlights several important elements in the intergenerational family firm succession process:

(1) The family firm: Family firms are unique organizational entities that are significantly different from their non-family counterparts (Chrisman et al. 2005). ${ }^{2}$

(2) The incumbent (owner-manager): Family firms are largely dependent on a single decision maker, the owner-manager (Feltham et al. 2005).

(3) The successor: Nepotism, a dominant relational element in family firms, can lead to the appointment of unqualified family members as management successors over the best qualified professional managers. (Miller 1993).

(4) The ownership transfer: Before an orderly transfer of a family firm from the incumbent to the successor can take place, the financial implications of marriage and inheritance laws need to be carefully considered. As such, ownership transfer has significant transaction costs (Bjuggren and Sund 2002).

(5) The financing sources for the transaction: Borrowing constraints may affect succession decisions in family firms, as noted by Kimhi (1997).

The financing strategies and capital structure choices of a family firm are associated with the stage in the life cycle of the firm. When an owner-manager starts a business, the financing

\footnotetext{
${ }^{2}$ The authors want to acknowledge the vast amount of literature on CEO-succession in non-family firms. These reviews, however, are outside of the scope of this paper.
} 
options are constrained because financial institutions are unlikely to provide debt financing when there is no collateral (Williamson 1988). One of the reasons for this phenomenon is that the early-stage family firm mostly relies on the effort and skills of the owner-manager, who contributes human capital to the business. On the family firm's balance sheet, such efforts are often reflected by intangible rather than tangible assets. Intangible assets are difficult to value. In addition, the time needed to transform an asset from intangible to tangible can be considerable.

The family firm succession stage is starkly different to the early stages of the business. At this later stage, the business has reached a certain maturity that reflects years of hard work by the owner-manager. The business has grown and typically has more tangible assets, such as machines, equipment or real estate. Thus, the family business reflects the vision for the company of its owner-manager. Because one of the owner manager's biggest worry is that the successor diminishes or destroys what the owner-manager has accomplished, he has an incentive to retain control of the family firm as long as possible. Such control can be achieved either directly or indirectly: (1) Directly by deferring the passing on of the managerial role to the next generation or (2) indirectly by choosing a more strategic form of succession financing. Because the firm is likely to require additional financing to cover succession related financing needs, the owner-manager must choose an appropriate financing package.

The need of succession-related financing arises because the transfer of ownership incurs significant transaction costs (Bjuggren and Sund 2002). The ownership transfer usually involves tax payments, such as inheritance and income taxes, compensatory payments to other family members or heirs, and/or payments to the predecessor, such as purchase prices for ownership shares. These succession-related financing needs arise and are in addition to the financial demands of the firm's general operating costs. These forms of ownership transfer are often accompanied by price payments that are likely to put financial demands on the successor's balance sheet that exceed the available private funds.

We posit that the use of debt financing for a family business transition is desirable for the owner-manager because of four general personal factors: (1) the incumbent's attitude toward debt, (2) the incumbent's financial knowledge, (3) the incumbent's risk propensity, and (4) the incumbent's experience with debt. Typically, the top management of a family firm prefers internal financing to external financing (Modigliani and Miller 1958; Donaldson 1961; Myers 1984; Barton and Gordon 1987 (Romano et al. 2001)) because it imposes fewer restrictions on the management team. In contrast, we expect that the owner-manager's attitude, particularly toward debt, in the context of family firm succession financing to be the opposite because the incumbent perceives restrictions imposed on the successor as an attractive feature that reduces the successor's autonomy (e.g., Myers 1984; Mizruchi and Brewster Stearns 1994). In addition, in situations that require substantial amounts of financing, such as for a family business succession transaction, internally generated funds might not be sufficient (Blanco-Mazagatos et al. 2007). According to Pecking Order Theory, 
the family firm will prefer debt to equity (Romano et al. 2001; Gallo et al. 2004). Using debt financing also provides a cost advantage over using equity capital, and this advantage is even higher for private firms, compared to public ones (Brav 2009).

We also expect that financial knowledge is associated with the owner-manager's understanding of financing alternatives and the intention to use debt. Several surveys have investigated the financial literacy of various population sub-groups (Lusardi and Mitchell 2008; Lusardi and Tufano 2009). The survey evidence shows that people aged 65 or older have lower debt literacy. In contrast, people with higher incomes have higher debt literacy. A more financially astute owner-manager is expected to better understand incentive alignment and possible tax benefits of using debt to help finance the business transition. A recent survey shows that entrepreneurs have the greatest knowledge of common financing alternatives, in particular bank loans and leasing (Seghers et al. 2012). We therefore argue that it is unlikely that owner-managers completely lack knowledge of debt as a financing alternative in the context of family firm succession. We further expect that prior experience with debt is associated with the owner-manager's intention to use debt. People gain experience with debt by taking out a student loan, car loan, home mortgage, or alternative financial services borrowing (Lusardi and Tufano 2009). We expect that the owner-manager is less likely to use debt financing for succession financing when prior bad experiences with such loans exist. We also expect that the owner-manager's risk propensity is associated with the intention to use debt. We expect that owner-managers with higher risk aversion are less likely to seek external debt financing.

We posit further that the owner-manager's intention to use debt financing is also associated with succession-related personal factors: (1) the need for family control, (2) succession planning and (3) succession experience. We expect that most owner-managers want the family firm to remain in the family. The easiest way to achieve this goal is to make sure that no equity is sold to non-family parties. In practice, however, this goal might be harder to achieve because two types of family firm succession events are possible: (1) planned succession and (2) unplanned succession. A planned succession event is one where the incumbent plans to retire at some future point. An unplanned succession event is one where the incumbent has to be replaced due to an unforeseen event such as a serious accident, illness or death. Proper succession planning considers both types of events. To deal with unforeseen events the manager-owner could buy an insurance policy that would provide funds to a family trust. The family trust would then provide a loan to the successor and a reasonable income to the spouse. We also expect that the intention to use debt financing is associated with succession experience. For example, it is often the case that the ownermanager has been involved in a family firm succession as the successor. We expect that the insight the incumbent has gained during such succession experience will be related to the intention to use debt in a future family firm succession. 


\subsection{A Conceptual Model of Succession Financing in Family Firms}

The previous section makes it clear that the current owner-manager plays a central role in succession planning, identifying a successor, organizing the financial aspects of the transfer, and, finally, passing on the family business. Because this paper focuses on succession within the family, the owner-manager is expected to remain more closely linked to the family business than would be the case if the business were sold to a third party. In this situation, most succession financing decisions are expected to be influenced by the owner-manager's personal characteristics, such as his/her attitude to debt, his/her risk propensity, his/her financial knowledge, and his/her experience with debt. In addition, personal successionrelated factors, such as the need for family control, succession planning and succession experience, are expected to influence financing decisions.

Our overall model is presented in Figure 1.

Insert Figure 1 about here

In this model, the need for family control provides a measure of the family social norms toward business succession because it reflects the expectations of the other family members regarding the succession outcome. Furthermore, the future succession financing decision may be subject to obstacles that are outside of the owner-manager's sphere of influence. Accordingly, our conceptual model accounts for feasibility considerations. That is, we incorporate a set of firm characteristics as controls in our conceptual model that may impede the owner-manager's decision-making freedom. For example, low firm profitability or high firm growth will limit the family firm's self-financing capability. In these sorts of cases, the owner-manager would likely be forced to utilize external financing and, consequently, would show a greater intention to engage in debt when financing successionrelated expenditures. ${ }^{3}$ Finally, we include other financing intentions in our model as additional controls to account for possible interdependencies between different financial sources for succession financing. Next, we develop our hypotheses in greater detail.

\section{General Personal Factors}

\section{Attitude toward debt}

Taking a social and behavioral science perspective on decision-making, an individual's attitude toward a certain behavior represents the most researched construct that determines behavioral choices. Attitudes reflect an individual's positive or negative evaluation of the expected outcomes from the decision in question (Ajzen 1991). Indeed, strategic decision-making tasks in family firms are found to be significantly influenced by the

\footnotetext{
${ }^{3}$ However, these variables will not be discussed in more detail as our paper focuses on the individual-level determinants of family firm financing.
} 
owner-manager's attitudes (Heck 2004). With regard to financial choices, a family firm's owner-managers are found to hold distinctive attitudes toward financing strategies (LópezGracia and Sánchez-Andújar 2007), which cause financial decisions to follow a peculiar financial logic (Gallo et al. 2004). This financial logic reflects both economic and noneconomic considerations (e.g., Gómez-Mejía et al. 2001). For example, the owner-manager may evaluate how a specific financial source will affect the distribution of profits to the family, the firm's cost of capital, the firm's future growth prospects, the family's reputation or the private benefits of control. It is the sum of these expectations that will then form his or her financial attitude.

Family firms' owner-managers usually hold very favorable attitudes toward internal financial sources such as retained profits or family wealth. However, regarding external financing, owner-managers commonly possess more positive attitudes toward debt financing than toward external equity financing (Romano et al. 2001). To date, research on decision-making has consistently found that an individual's attitude is a significant predictor of behavioral intentions. In general, a more favorable attitude towards a behavior should lead to a stronger intention to perform the behavior (Ajzen 1991). Following multiple studies that have shown the validity of the general attitude-intention relationship in various business and non-business contexts (e.g., Armitage and Conner 2001), we expect that this relationship will also apply to the succession financing context. Accordingly, we hypothesize the following:

H1: A more favorable owner-manager's attitude toward debt financing is positively related to the intention to use debt for succession financing.

\section{Risk propensity}

Decision making in family firms is significantly influenced by the owner-manager's perception of the risk associated with the decision (Claver et al. 2008). In turn, risk perceptions are influenced by an individual's risk propensity (Sitkin and Weingart 1995). An individual's risk propensity describes his or her tendency to take or avoid risk (Sitkin and Pablo 1992). Accordingly, risk propensity is a central personal disposition in the decisionmaking process (e.g., Mullins and Forlani 2005) that particularly affects financial decision making in close, privately held firms (Michaelas et al. 1998). Although the risk propensity in family firms is subjective and may vary depending on the owner-managers' characteristics (Jones et al. 2008), recent research suggests that family firm owner-managers generally show a high level of risk aversion (e.g., McConaughy et al. 2001; Mishra and McConaughy 1999). Individuals with a lower risk propensity (risk avoiders or risk averse) perceive the risks associated with a particular decision option to be higher than those individuals who have higher risk propensities (risk seekers). Therefore, those who are more risk averse choose less risky options (Mullins and Forlani 2005).

The succession process is typically risky for family firms and the owning family because a succession failure risks the loss of family control and family wealth. Financing decisions can 
add to these risks. For example, utilizing debt is closely related to the bankruptcy risk of a firm (Parsons and Titman 2008), especially when existing debt levels are high or excessive. Thus, raising debt increases the family's risk of losing both financial wealth (BlancoMazagatos et al. 2007) and socio-emotional wealth (Gómez-Mejía et al. 2007). A high aversion to control risks is also found to motivate a family firm's owner-managers to use less debt and to rely more on retained earnings (Mishra and McConaughy 1999). Accordingly, family firms may mitigate succession-related risks by employing less risky forms of financing, such as retained earnings and/or family wealth. However, we argue that owner-managers who are more risk averse will perceive that the risk of using debt for succession financing is high. Conversely, owner-managers who are risk takers will not regard debt financing as overwhelmingly risky and are thus more likely to engage in debt financing within the succession process. We therefore hypothesize the following:

H2: A higher owner-manager's risk propensity is positively related to the intention to use debt for succession financing.

\section{Financial knowledge}

The knowledge and knowledge accumulation of the owner-managers represent a special resource for family firms (Cabrera-Suárez et al. 2001; Habbershon et al. 2003); both are significant components of effective decision making (Jensen and Meckling 1992). Specialized knowledge allows individuals to identify, solve, or even predict and anticipate problems in a specific domain (Leonard and Sensiper 1998). Specialized knowledge permits a reduction in uncertainty (Beijerse 1999) and remedies the effects of bounded rationality on decision making (March and Simon 1958). As such, the need for using decision heuristics is reduced, thus alleviating the occurrence of decision biases and, consequently, improving the decisionmaking quality.

Similarly, financial knowledge is a critical factor within financial decision-making because capital acquisitions are directly affected by the level of financial information available to and known by the owner-manager (Van Auken 2001). Research shows that limited knowledge of financing alternatives frequently causes suboptimal financing decisions (Seghers et al. 2012). For example, the decision of a family firm to borrow money is found to be influenced by the owner-manager's knowledge about the types and the functions of the available financial resources (Michaelas et al. 1998). Succession may cause additional financial demands for the owning family and the family firm because of possible inheritance taxes, realignment expenditures, or cash withdrawals to family members who do not have a stake in the business (De Massis et al. 2008). These demands frequently require external financing because the internal financial capacities of the firm and the family are limited (Kimhi 1997). The reluctance of family firms to use external financing is partly due to ingrained, long-term prejudices and norms maintained by the family (Gallo et al. 2004). An owner-manager who possesses financial knowledge and skills regarding available financial sources, financial contracting and the functioning of financial sources and capital markets is better able to realize the value of external financial sources for the business and to overcome ingrained 
prejudices against debt. Furthermore, the more an owner-manager knows about the types and functions of existing financial products and financial institutions, the less dependent the owner-manager is likely to be on the traditionally used financial sources such as internal finances or family wealth. Additionally, increased financial knowledge should increase a firm's internal financial planning and monitoring activities, which are likely to result in less demand for monitoring rights by potential lenders. Therefore, we suggest that ownermanagers with increased financial knowledge will be more open to debt financing and, therefore, more likely to use debt for succession financing. Thus, we hypothesize the following:

H3: An increased level in the owner-manager's financial knowledge will be positively related to the intention to use debt for succession financing.

\section{Experience with debt}

In the absence of perfect information, decisions must, at least in part, be based on prior experiences and judgments (Simon 1987). Prior experience represents part of an individual's knowledge (Jensen and Meckling 1992). However, knowledge gained from experience is clearly distinct from knowledge acquired through education or training, as similar experiences do not always lead to similar increases in knowledge (Quinones et al. 1995). A general research finding is that experienced individuals utilize richer decision-making and problem-solving strategies and are better able to evaluate the appropriateness of those strategies (Johnson 1988). Additionally, experience is most beneficial in less structured and more complex decision contexts (Abdolmohammadi and Wright 1987), such as succession planning or succession financing. However, experienced decision makers have the tendency to become increasingly channeled by their past experiences (Shepherd et al. 2003), which makes it difficult for them to recognize new variables and situational changes (Tversky and Kahneman 1974). Accordingly, past experience with financing options and the behavior of financial suppliers is likely to create expectations about the future behavior of these financial suppliers. These expectations, in turn, will direct future financial decisions in family firms. Indeed, the owner-managers that have favorable prior experiences with debt financing are found to be less cautious about raising debt, whereas owner-managers with negative prior experiences are less likely to engage in new debt financing (Michaelas et al. 1998). An owner-manager's positive experience with debt may be the result of favorable credit conditions, credit acceptance or the general behavior of financial institutions in prior years. Consequently, we argue that owner-managers who have had positive experiences with debt suppliers in the past will likely utilize debt for financing succession-related expenditures. Therefore, we hypothesize the following:

H4: Stronger positive experiences with debt suppliers will be positively related to the intention to use debt for succession financing. 


\section{Succession-Related Personal Factors}

\section{Need for Family Control}

A narrow definition of a family firm typically includes the owner-manager's desire for a generational transfer of the firm within the family (e.g., Barach and Ganitsky 1995). Indeed, the wish to keep the firm within the family is the most important driver of succession activities (e.g., Sharma et al. 2003b). The need to maintain control of the family business is likely to increase when the family expresses their commitment and loyalty to the business, when they demonstrate pride in the business or when there are family members who are willing to continue the business. The evolving need for family control reflects a specific social norm that is likely to affect the owner-manager's decision making (Pearson et al. 2008). There are numerous reasons for a family to retain control of a business, and these reasons include factors like the private benefits of control, such as amenity potential or reputational considerations, or the maintenance of an income source for the family (GómezMejía et al. 2007; Burkart et al. 2003). Accordingly, a greater need for family control should increase the engagement of an owner-manager in succession management activities such as succession planning.

Furthermore, the need to maintain control within the family directly affects the ownermanager's financing decisions (e.g., Romano et al. 2001). Empirical studies on family firm financing generally reason that a high need for family control is the major cause of an owner-manager's aversion to external financing (e.g., Mishra and McConaughy 1999; Gallo

et al. 2004). For example, the use of debt financing for succession-related expenditures may affect family control because debt suppliers frequently require control and monitoring rights. In addition, the greater leverage increases the firm's bankruptcy risk, which can result in a complete loss of family wealth and control. Therefore, we argue that in family firms with a strong desire to maintain family control, owner-managers will prefer internal rather than external financing for succession-related expenditures. Accordingly, we hypothesize the following:

H5: A greater need for family control will be negatively related to the intention to use debt for succession financing.

\section{Succession Experience}

Previous succession experience has been recognized as an important determinant of a family firm's succession performance (Le Breton-Miller et al. 2004). Astrachan, Klein and Smyrnios (2002) regard a family firm's succession experience as occurring on an exponential continuum. Each successful succession adds valuable experience to the family and to the firm (Cabrera-Suárez et al. 2001). Empirical data on succession failure among family firms verifies the positive influence of previous succession experience on succession performance: although only $30 \%$ of family firms survive the first generation, $50 \%$ of these secondgeneration family firms survive the subsequent succession process and reach the third generation (Miller et al. 2003). Accordingly, if owner-managers have already experienced a 
succession process, it is likely that they are more aware of the difficulties and problems that may occur during the succession process. For example, they may be more likely to anticipate succession expenditures that arise from sibling conflicts. Additionally, they may be more likely to engage in financial planning activities, such as an accumulation of family wealth or a steady increase in the firm's internal financing capacity, both of which reduce the need for external financing during the succession process. Furthermore, research indicates that descendants are less inclined and less willing to bear business risks compared with their parents (e.g., Kaye and Hamilton 2004), which may also lead to a decreased utilization of debt. In addition, later-generation family firms exhibit increased loss aversion, goal misalignment and intra-family conflicts that also reduce the use of debt (Schulze et al. 2003). We therefore argue that owner-managers who have already experienced a succession are less likely to use debt for succession financing. Accordingly, we hypothesize the following:

H6: Succession experience will be negatively related to the intention to use debt for succession financing.

\section{Succession Planning}

Researchers have long emphasized the importance of succession planning for ensuring the continuity and prosperity of family firms (e.g., Brockhaus 2004). Despite this emphasis, succession planning appears to be left to chance by many family firms (e.g., Sharma et al. 2000), primarily because the owner-manager is resistant to succession planning (Ibrahim et al. 2001). This aversion may result from the negative emotions that occur when faced with his or her own mortality (Lansberg 1988). Succession planning - tacit or formal - involves all of the actions that are necessary for transferring leadership and ownership (Le Breton-Miller et al. 2004). Among those actions are successor selection and training, the steps of leadership transfer, compensation payment planning, and tax planning (e.g., Lansberg 1988).

Succession-planning activities may affect succession-related financial needs in different ways. First, when owner-managers engage in planning early, they can pursue activities that will reduce the need for external financing, such as an ongoing transfer of ownership during the owner-manager's lifetime. However, family firms are likely to need outside financing as a part of the succession process (De Massis et al. 2008). In this way, deliberate succession planning may enable the owner-manager to foresee the need for external financing during succession. Because debt is preferred to equity financing in family firms (e.g., Romano et al. 2001), succession planning may increase the owner-manager's intention to use debt financing for succession-expenditures. Furthermore, succession planning may include tax planning. It is widely accepted that debt carries tax benefits (Modigliani and Miller 1963), and family firms are known to develop financial strategies to reduce their tax burden (Haynes et al. 1999). Indeed, research shows that planning increases the likelihood that family firms will use debt financing (Romano et al. 2001). Accordingly, we argue that owner- 
managers who are actively engaged in succession planning will use debt financing to reduce the expected tax burden. We therefore hypothesize the following:

H7: Succession planning will be positively related to the intention to use debt for succession financing.

\section{Methodology}

\subsection{Sample}

The data of this study were gathered via a mailed survey in 2008, which is a common method for obtaining data in family firm research (e.g., Eddleston and Kellermanns 2007). The initial sample was drawn from the Hoppenstedt database, the largest database on German companies. Smaller companies, referred to as life-style businesses (Schulze et al. 2003), are likely to be faced with low succession-related expenditures and, consequently, should have only minor needs for external financing. We therefore included only firms with minimum sales of EUR 700,000 in 2007 (approximately U.S. \$1 million) in our sample.

To determine whether a firm is a family firm, we used the power subscale of the F-PEC scale to assess the influence of the family over the firm (Klein et al. 2005). Consistent with Klein et al. (2005), we analyzed the family's ownership, family management, and family board positions for the firms by combining information from the Hoppenstedt database with that from the Creditreform and Bürgel company databases and by reviewing the relevant sections from company web pages (i.e., 'about us' or 'firm history'). We randomly selected 2,200 firms and sent them a questionnaire with a personalized cover letter to the ownermanager and an addressed return envelope. After three reminders, a total of 362 questionnaires were received. The response rate of $16.5 \%$ is similar to that of other recent studies on family firms in Germany (e.g., Pieper et al. 2008). However, because some questionnaires were deemed unusable due to missing data, our final sample included 187 German family firms. Accordingly, we checked for potential differences between our initial sampling and the sample to be used in the study, applying an ANOVA. We did not identify any statistically significant differences between the two samples with regard to firm age, size, industry, growth or profitability.

Because the variables in our study came from answers that were provided by a single respondent, common method variance may have affected our empirical results. Following Podsakoff et al. (2003), we assured the respondents of the confidentiality of their answers to reduce any evaluation apprehension, separated the measurement of the predictor and criterion variables, counterbalanced the question order, and improved our scale items (as suggested by Tourangeau et al. 2000). Additionally, a confirmatory factor analysis was conducted to identify if there was any common method bias (Podsakoff et al. 2003). We controlled for common method variance by explicitly incorporating the effects of a latent method factor on each observed item. The shared variance in our model is $0.09 \%$. Thus, this test provided no evidence for a common method bias in our data. Additionally, we tested 
for potential non-respondent bias in our study. As late respondents are considered more similar to non-respondents (Kanuk and Berenson 1975), we divided our data into early and late respondents depending on when the questionnaires were received. We analyzed the differences between early and late respondents using an ANOVA, a method that earlier research suggests is appropriate when data from non-respondents is not available (e.g., Eddleston et al. 2008). However, we did not observe any statistically significant differences between the two groups, indicating that non-response bias is not a problem in our study.

\subsection{Measurements}

Most of the variables in this study were measured using adapted versions of scales and measures from previous studies. We assessed content and internal validity through expert interviews and conducted a pilot study with eight owner-managers of family firms. Before sending out the final questionnaires problematic items were identified and re-worded or deleted based on feedback from consultants that specialize in family businesses and from the participants in the pilot study. The measurement scales of all multi-item constructs used in this study exceeded the 0.7 threshold for Cronbach's Alpha and, thus, demonstrated satisfactory reliability (Nunally 1978).

\section{Independent Variables}

First, this study includes a variety of general personal factors that were predicted to influence succession financing. These factors are measured as follows. Attitude is commonly assessed with items that are related to the overall favorable or unfavorable assessment of the behavior in question, which is captured by such attribute dimensions as good-bad, harmful-beneficial, pleasant-unpleasant, or likeable-dislikeable (Ajzen 2001). Accordingly, we measured an owner-manager's attitude toward debt financing with four items, which included the evaluative adjectives good, useful, beneficial, and wise. Each item was measured using a seven-point Likert scale that ranged from strongly disagree $(=1)$ to strongly agree $(=7)$. The items were averaged to yield an attitude score $(\alpha=0.94)$.

An individual's risk propensity reflects his or her tendency to take or avoid risk (Sitkin and Pablo 1992). Risk propensity is context-related and may vary within different decisionmaking areas (Sitkin and Weingart 1995). As this study addresses financial decision making, we used a measure for financial risk-taking propensity. Following earlier research (Mullins and Forlani 2005), risk propensity was operationalized using an adapted version of the Risk Style Scale (Schneider and Lopes 1986). The number of lottery choices was summed up as a risk propensity indicator that ranged from 0 to 5.

Research on individual knowledge distinguishes between objective knowledge - accurately stored information - and subjective knowledge - beliefs about the state of knowledge (e.g., Moorman et al. 2004). Specifically, this study assesses the family firm ownermanager's financial knowledge as the amount of accurately stored financial information. Previous studies have measured the level of objective knowledge through a series of 
domain-specific questions (e.g., Moorman et al. 2004). Similarly, financial knowledge in our study was measured by a knowledge quiz that included six propositions related to business financing with different levels of difficulty. A sample proposition is "Trade credit financing can easily cost a yearly interest rate of $30 \%$ or more". The respondents were asked to indicate if they agree or disagree to the respective proposition. The number of correct answers was summed up as a financial knowledge indicator that ranged from 0 to 6 .

Financial experience is acquired over time. It reflects an individual's positive and negative appraisal of the outcomes of relationships with capital suppliers. Particularly positive experiences may affect future financial decisions. Because our study is focused on debt financing, we used a single item to measure the individual's experience with debt in terms of his/her prior positive experience with debt suppliers using a seven-point Likert scale (1 = strongly disagree to 7 = strongly agree).

This research also included succession process-related factors. The need for family control may manifest itself in the attitudes of the owner-manager or the family's approach toward family members that work, manage, and/or own the firm. We measured the need for family control with a previously validated three-item scale that considers the variety of forms that family control may take (Smyrnios et al. 1998). For example, one item was, "Family ownership and control is important when considering senior appointments". These items were measured using a seven-point Likert scale ( $1=$ strongly disagree to $7=$ strongly agree) and were averaged to yield a need for family control score $(\alpha=0.71)$.

Succession experience enhances the family firm's and its owner-manager's knowledge of the succession process. Because this experience is an exponential continuum for the firm (Astrachan et al. 2002), it was measured by the natural log of the number of succession events experienced by the owning family $(+1)$ to capture the logic of the learning curve. Succession planning involves a broad variety of different actions, such as developing a formal succession plan, selecting a successor, and selecting a retirement date (e.g., Lansberg 1988). Succession planning was assessed using a dichotomous variable that was assigned a value of 1 if the respondent indicated that at least one succession-planning activity had already been initiated.

\section{Dependent Variable}

Intention reflects an individual's plan to perform a particular behavior in the future (Ajzen 1991). We evaluated the respondent's intentions to finance succession expenditures with debt using a dichotomous item. Dichotomous dependent variables are common in entrepreneurship and family firm research (e.g., Blanco-Mazagatos et al. 2007; Riding et al. 2012). Within the succession process, debt can be raised by the firm, the incumbent or the successor. The dependent variable was assigned a 1 if the respondent indicated he or she planned to use debt for succession financing; this debt could be raised by the firm, the incumbent and/or the successor. This variable was assigned a 0 if there was no plan to use debt. 


\section{Control Variables}

We employed five feasibility controls in our analysis. First, we controlled for firm-specific variables to account for factors that could impede the feasibility of a desired behavioral choice. Specifically, we included firm size, growth, profitability and ownership dispersion in our analyses because these variables have been found to influence family firm financing behavior (e.g., Romano et al. 2001; Gallo et al. 2004; Blanco-Mazagatos et al. 2007; Schulze et al. 2003). Growth was a self-reported measure of the family firm's three-year average sales growth (2004-2007), size was operationalized using the natural logarithm of net sales in 2007, and profitability was assessed by the firm's return on assets (ROA) in 2007 (e.g., Blanco-Mazagatos et al. 2007). Ownership dispersion was measured by the number of a firm's shareholders. Lastly, our research assumes that the existence of an advisory board influences the succession processes (e.g., Chittoor and Das 2007). We assigned a 1 if the respondent indicated that the firm had established an advisory board. In addition, it is very likely that family firms would use multiple financial sources for any succession expenditures. Research results suggest that family firms prefer to use internal finance (i.e., family wealth and retained earnings), followed by external debt, with external equity used only as a last resort (e.g., Gallo et al. 2004). In light of these findings, our model controlled for any plans to use other financial sources for succession financing by incorporating the intention to use a) family wealth, b) retained earnings, and c) external equity.

\section{Analyses and Results}

\subsection{Main Analysis}

Given that our dependent variable, the intention to use debt for succession financing, is a dichotomous variable, binary logistic regression was used to analyze the obtained data. The data analysis was performed using PASW Statistics 18.

Insert Table 1 about here

Descriptive statistics and Pearson correlations for our independent and dependent variables are presented in Table 1. The correlations between the independent variables are below the critical values that would indicate serious multi-collinearity problems in the data (Hair et al. 1998). Prior to the binary logistic regression analysis, a further investigation of mean values and correlations revealed some interesting findings. First, $34 \%$ of family firms intend to use debt financing for succession expenditures. However, it is more common for the ownermanagers to intend to use family wealth and retained earnings, the latter being strongly, negatively correlated to the intention to use debt financing. The owner-manager's attitude toward debt is neutral and positively correlated with his or her financial knowledge, debt usage experience and the size of the firm. Moreover, the existence of an advisory board is positively correlated with an owner-manager's attitude toward debt and with the number of 
shareholders. In our sample, only $69 \%$ were already engaged in succession-planning activities. More interestingly, succession experience and succession planning are not significantly correlated to each other. Last, nearly all of the owner-managers appeared to be averse to financial risks because our descriptive results indicate a very low average risk propensity score of 1.1.

Insert Table 2 about here

The results of our binary logistic regression analyses are presented in Table 2 . We used five different models to test the robustness of our estimates and to investigate each factor group's contribution to the conceptual model's explanatory power. First, we entered the firm variables and the intentions to use other financial sources as controls (Model 1). Subsequently, we added the general personal factors into Model 2. To analyze our full conceptual model, the succession-related personal factors were entered into Model 3. Finally, we split our sample according to the planned date of succession (less than 10 years or 10 or more years) and repeated our analysis (Models 4 and 5). Following previous exploratory studies (e.g., Ucbasaran et al. 2003), we attempted to avoid Type II errors. Accordingly, we selected 0.1 as the level of significance in our analyses. The results from Model 1 through Model 3 are presented next; the split sample analysis (Models 4 and 5) is presented in section 4.2 .

All of our models were statistically significant and showed a good fit to the data as indicated by the Hosmer and Lemeshow tests, with $p$ values being greater than 0.05 (Hosmer and Lemeshow 1989). Before testing our hypotheses, our control variables were entered into Model 1. Model 1 achieved statistical significance with an explained variance of $28.5 \%$ (Nagelkerkes $\mathrm{R}^{2}$ ). To test our hypotheses, we first entered only the general personal factors for Model 2 and subsequently tested our full conceptual model by adding the hypothesized succession-related personal factors for Model 3. The inclusion of general personal factors significantly improved our model $\left(\Delta \chi^{2}=17.113, p<0.01\right)$. Model 2 explains $38.1 \%$ of the dependent variable's variance. Our full conceptual model (Model 3) achieved statistical significance with an explained variance of $46.6 \%$. The inclusion of succession-related personal factors led to a significant improvement in the model $\left(\Delta \chi^{2}=19.490, p<0.01\right)$. The predictive accuracy of Model 3 was 78.6\%.

The first set of hypotheses investigated the influence of general personal factors on the owner-manager's intention to use debt for financing succession expenditures. Our hypotheses were mainly supported by our results. First, it was predicted that the ownermanager's attitude toward debt would positively influence the intention to use debt. Indeed, the attitude toward debt $(\beta=0.275, p<0.10)$ was found to be significant and positively related to a person's intention to use debt for succession financing, thus supporting Hypothesis 1. However, Hypothesis 2 was not supported by our data. An ownermanager's risk propensity had a positive, but not significant, effect on the intention to use 
debt for succession financing $(\beta=0.123$, n.s.). Hypothesis 3 proposed that the level of the owner-manager's financial knowledge would be related to his/her intention to use debt financing for succession expenditures. Our results revealed a strong and positive relationship between financial knowledge $(\beta=0.414, p<0.01)$ and the intention to use debt. Additionally, Hypothesis 4 , which stated that the strength of positive debt experiences would be related to the owner-manager's debt usage intention, was not supported by our analysis. The level of positive experience with debt ( $\beta=0.226$, n.s.) was not significantly related to an owner-manager's intention to use debt financing. The inclusion of the general personal factors increased our model's explained variance by $9.6 \%$.

The second set of hypotheses explored the influence of succession-related personal factors on debt use intention for succession financing. First, Hypothesis 5 , which postulated that a greater desire for family control would be associated with the debt usage intention of a family firm's owner-manager, was not supported by our data ( $\beta=-0.223$, n.s.). However, the expected negative relationship between prior succession experience and the intention to use debt financing for succession expenditures (Hypothesis 6 ) was strongly supported by our data analysis $(\beta=-1.293, p<0.01$ ). Finally, Hypothesis 7 predicted a relationship between succession-planning activities and the intention to use debt. Here, we found support for a positive relationship between succession-planning activities ( $\beta=1.069$, $p<0.05)$ and the intention to use debt for succession financing. Adding the successionrelated personal variables to our model increased the explained variance by $8.6 \%$. Finally, we have to acknowledge the influence of the firm's control variables on the debt usage intention. The firm's growth had a strong and positive effect $(\beta=0.051, p<0.01)$ on an owner-manager's intention to use debt, whereas the firm's profitability and ownership dispersion were found to have a negative effect $(\beta=-0.023, p<0.05$ and $\beta=-0.257, p<$ $0.10)$. Additionally, the intention to use retained earnings and external equity were significantly related to our dependent variable: while the intention to use retained earnings had a strong negative effect $(\beta=-1.757, p<0.001)$, the intention to use external equity was found to have a significant and positive effect $(\beta=1.926, p<0.05)$.

\subsection{Split Sample Analysis}

Intentions are generally accepted as valid predictors of future behavior (e.g., Armitage and Conner 2001, Ajzen et al. 2009). However, it is possible that actual behavioral decisions will be different from an individual's behavioral intentions, particularly when the actual behavior is in the distant future. We therefore divided our sample into two groups: one group is likely to perceive the succession as more pressing, while the other group is likely to perceive the decision as being further in the future. Following conventional wisdom, succession planning must begin at least 10 years in advance to ensure a smooth transition. We thus set the split date at 10 years and repeated our conceptual model. Model 4 shows the results for the sample group that expects succession to occur in less than 10 years, while Model 5 shows the results for the group of family firms that assumes succession will take place in 10 or more years. Both models were statistically significant, showed a good fit to the data and had 
a high predictive accuracy (80.7\% and $79.8 \%$ ). The explained variance was $51.4 \%$ (Model 4 ) and $54.4 \%$ (Model 5). The results of our split sample analysis largely support our findings. In both groups, succession experience negatively influences our dependent variable. For those firms that are likely to perceive succession to be more pressing, the individual's attitude is a more prominent predictor of the debt usage intention (Model 4). In contrast, financial knowledge was a major influence on the intention to use debt for succession financing in the other group. The statistical insignificance of succession planning in our split sample analysis can be explained by missing variance.

\section{Discussion, Implications, and Limitations}

Business succession is a challenging event. Poor succession planning and succession financing choices can result in the firm's failure. However, family firms cannot avoid succession because its occurrence is driven by the owner-manager's biological clock (Lansberg 1999). This study attempted to extend previous research on family firm succession by developing and empirically testing a conceptual model of succession financing behavior. Although succession financing represents a significant precondition for the successful intergenerational transfer of family firms (De Massis et al. 2008), this study is, to the best of our knowledge, the first of its kind. We relied on insights from social psychology, corporate finance, and succession research, to study the owner-manager's intention to use debt for financing succession expenditures.

The empirical results of our study provide support for the multi-dimensional analyses of succession issues in family firms because we found significant relationships between the intention to use debt financing, general personal factors, succession-related personal factors, and firm factors. Accordingly, our results contribute to the existing empirical research on family firm succession because these studies usually include only individual or firm factors in their analyses (for a review see, e.g., Chittoor and Das 2007). Additionally, our findings are also important for research on general family firm financing behavior because little is known about how and why family firms utilize particular financial resources (BlancoMazagatos et al. 2007).

To date, the determinants most studied in the context of succession are the incumbent's personal characteristics and relationships with the other family members (e.g., Barach and Ganitsky 1995; Cabrera-Suárez et al. 2001). Consistent with the arguments developed earlier, we found that attitudes toward debt and financial knowledge are significant predictors of the owner-manager's intention to use debt financing. This finding contributes to the resource-based view of the family firm (e.g., Cabrera-Suárez et al. 2001) because it highlights the importance of knowledge and knowledge accumulation as a key resource for family firms. Moreover, these findings underline the decisive role of knowledge in decisionmaking tasks in family firms because knowledge appears to allow owner-managers to overcome existing prejudices against external finance, particularly with respect to debt. This finding is especially noteworthy because family firms are known to forego growth 
opportunities rather than use external financing, which is a choice that can impede the firm's future performance (e.g., Gallo et al. 2004). Although risk propensity is a key personality trait in entrepreneurship research (e.g., Mullins and Forlani 2005), we did not find significant support for a positive relationship between individual risk propensity and an owner-manager's intention to use debt financing. This finding may result from the general financial risk aversion of a family firm's owner-managers.

Furthermore, we found that succession process-related factors impact the owner-manager's intention to use debt financing for succession expenditures. In particular, succession experience was found to be a strong determinant. Previous succession experience generates knowledge that allows the owner-manager to foresee potential problems and related expenditures that will arise with the succession. Thus, anticipatory decisions become possible, which, in the long term, limits the succession-related expenditures and thus the need for external financial sources. Limiting expenditures, in turn, facilitates the succession process because a family firm's owner-managers are found to be averse to external financing (e.g., Gallo et al. 2004). Thus, we add to the existing succession literature that highlights the importance of experience for succession performance (e.g., Le Breton-Miller et al. 2004). Moreover, we found succession planning to be a significant determinant of the debt use intention. Planning increases the succession process's transparency and may reveal potential succession-related expenditures in advance. More interestingly, succession experience and succession planning were not significantly correlated. Accordingly, having experienced a succession did not mean that family firm owner-managers were engaged in succession-planning activities. However, the timely engagement in succession-planning activities may prevent any negative effects from unforeseen events, such as the ownermanager's unexpected death. This finding is particularly noteworthy because it highlights that the emotional aspects related to succession, such as being faced with one's own mortality (Lansberg 1988), may increase the owner-manager's resistance to engaging in succession management activities, such as succession planning. This resistance, in turn, influences succession performance, particularly in later generational transfers where formal succession planning is a critical factor due to increased firm complexity.

Finally, three of our firm-specific controls were found to significantly influence the ownermanager's intention to use debt for succession financing. In particular, a firm's growth and profitability affect succession-financing decisions. Both higher growth and lower profitability are likely to force the owner-manager to use external debt financing because of limited selfgenerated financial capacity (Kimhi 1997). Accordingly, firm variables affect the feasibility of certain financial behaviors. In addition, our findings suggest that family firms exhibit financial behavior that is consistent with the Pecking Order hypothesis (López-Gracia and Sánchez-Andújar 2007). However, when adopting a broader perspective on our findings, we find that individual-level factors (including financial intentions) are the most important determinants of succession financing decisions, accounting for approximately $75 \%$ of the conceptual model's explained variance. 
The results from our study also have practical implications. First, as indicated by our descriptive results, only one third of all family firms intend to engage in debt financing for succession, while the anecdotal evidence suggests that most family firms will need debt financing to successfully pass the baton (L-Bank 2006). Family firm owner-managers should, therefore, be aware of the existing discrepancy between their expectations and the probable reality and be prepared to adjust their intentions accordingly. Moreover, family firm owner-managers should engage in succession-planning activities because these activities may help to determine the amount of financing needed or even reduce the expenditures by leading the owner-managers to act on expectations. The value of succession planning is of particular importance for family firms because banks usually consider a family firm's succession-planning activities in their credit scoring systems. Furthermore, a steady increase of financial knowledge will improve the financial decisionmaking in family firms and may help to overcome prejudices against certain categories of financing, especially when succession is perceived to be well in the future. Family firm owner-managers should also be aware that their financial decisions are driven by their attitudes. Negative attitudes toward debt may prevent them from using debt financing even if debt is needed for a successful generational transfer. Additionally, debt suppliers should rethink today's transaction-oriented approach of doing business in favor of a more relationship-based lending approach. This approach can more positively affect the personal experience of a family firm's owner-manager because positive experiences with debt and its suppliers can influence the future financing decisions of family firms, particularly when succession is perceived to be more pressing. Lastly, policy makers and capital suppliers can increase the likelihood of successful succession by providing sufficient financial knowledge and appropriate information about the importance of succession-management activities like succession planning.

There are a number of limitations in this study that suggest avenues for future research. First, consistent with prior research (e.g., Sharma et al. 2003b), this study takes an ownermanager-centric view on succession-related decision-making tasks. However, other stakeholders, especially other family members, are important and must be considered when transferring power and ownership in family firms (e.g., Lansberg 1988; Stavrou 2003). To this end, recent research indicates that succession outcomes are influenced by relational issues such as conflicts between family members (e.g., Eddleston and Kellermanns 2007). As these relational dimensions are not included in our model, future research could significantly add to our knowledge by including aspects of the predecessor-successor relationship to the study of succession financing. Furthermore, contrasting succession financing decisions with a numerical measure for existing family wealth could enhance our conceptual model because our results support the view that family firms strive to use internal funding first. Second, because we investigate behavioral intentions in this study, we may face the problem of inflated intentions; it is always possible that actual behavioral decisions will be different from an individual's behavioral intentions. However, research consistently finds that behavioral intentions are the most important predictor of future behavior (Ajzen et al. 2009), such as the use of debt (Grichnik et al. 2011). We therefore split 
our sample into two groups to investigate the effect of succession timing and found largely consistent results regarding our core conclusion about which personal factors are important in this context. However, future research could enhance our knowledge by verifying our results with a measure of actual behavior instead of behavioral intentions. Third, our study relies on self-reported data. Although objective measures of financing choices would have been desirable, we could not obtain this information because the family firms in our sample were not publicly traded. Furthermore, because all information was obtained from a single respondent, our study is exposed to the risk of common method bias. However, after conducting a post hoc-test for common method bias (Podsakoff et al. 2003), our analysis did not indicate any significant concerns. Finally, our study employed a demand-side approach to financing decisions by researching the behavior of the family firm's owner-manager. However, financial decision-making in family firms might be constricted due to supply-side behavior, such as credit rationing by banks (Stiglitz and Weiss 1981). On the one hand, the likelihood of supply-side constraints is rather low because our study was conducted prior to the credit crunch and governmental and regulatory influence on the banking system (Shin 2009). On the other hand, the owner-manager's intention to use debt financing and the actual use of debt financing could be affected by the successor's ability to obtain debt financing from banks. Therefore, future studies incorporating variables that reflect both demand- and supply-side behavior would significantly add to our understanding of financing behavior.

\section{Conclusions}

In conclusion, our study provides the first conceptual model of succession financing and a thorough empirical analysis of the succession financing decisions of owner-managers in family firms. Our results demonstrate that general personal factors, succession-related personal factors and firm factors impact the owner-manager's intentions and, thus, the likelihood of using debt for succession financing. Specifically, the owner-manager's financial knowledge, attitude toward debt, succession planning, and prior succession experience are found to determine succession-financing decisions. Accordingly, to complement our work, future research should continue to take a multi-dimensional perspective on succession and incorporate personal relationship issues into the analysis of succession financing.

\section{References}

Abdolmohammadi, M., \& Wright, A. (1987). An examination of the effects of experience and task complexity on audit judgments. Accounting Review, 62(1), 1-13.

Ajzen, I. (1991). The theory of planned behavior. Organizational Behavior \& Human Decision Processes, 50(2), 179-211.

Ajzen, I. (2001). Nature and operation of attitudes. Annual Review of Psychology, 52(1), 2758.

Ajzen, I., Czasch, C., \& Flood, M. G. (2009). From intentions to behavior: Implementation intention, commitment, and conscientiousness. Journal of Applied Social

Psychology, 39(6), 1356-1372. 
Armitage, C. J., \& Conner, M. (2001). Efficacy of the theory of planned behaviour: A metaanalytic review. British Journal of Social Psychology, 40(4), 471-499.

Astrachan, J. H., Klein, S. B., \& Smyrnios, K. X. (2002). The F-PEC scale of family influence: A proposal for solving the family business definition problem. Family Business Review, 15(1), 45-58.

Barach, J. A., \& Ganitsky, J. B. (1995). Successful succession in family business. Family Business Review, 8(2), 131-155.

Barton, S. L., \& Gordon, P. J. (1987). Corporate strategy: Useful perspective for the study of capital structure? Academy of Management Review, 12(1), 67-75.

Beijerse, R. P. u. (1999). Questions in knowledge management: Defining and conceptualising a phenomenon. Journal of Knowledge Management, 3(2), 94-110.

Bennedsen, M., Meisner Nielsen, K., Perez-Gonzalez, F., \& Wolfenzon, D. (2007). Inside the family firm: The role of families in succession decisions and performance. Quarterly Journal of Economics, 122(2), 647-691.

Bjuggren, P.-O., \& Sund, L.-G. (2002). A transaction cost rationale for transition of the firm within the family. Small Business Economics, 19(2), 123-133.

Blanco-Mazagatos, V., de Quevedo-Puente, E., \& Castrillo, L. A. (2007). The trade-off between financial resources and agency costs in the family business: An exploratory study. Family Business Review, 20(3), 199-213.

Brav, O. (2009). Access to capital, capital structure, and the funding of the firm. Journal of Finance, 64(1), 263-308.

Brockhaus, R. H. (2004). Family business succession: Suggestions for future research. Family Business Review, 17(2), 165-177.

Burkart, M., Panunzi, F., \& Shleifer, A. (2003). Family firms. Journal of Finance, 58(5), 21672202.

Cabrera-Suárez, K., De Saa-Pérez, P., \& Garcia-Almeída, D. (2001). The succession process from a resource- and knowledge-based view of the family firm. Family Business Review, 14(1), 37-46.

Chittoor, R., \& Das, R. (2007). Professionalization of management and succession performance-a vital linkage. Family Business Review, 20(1), 65-79.

Chrisman, J. J., Chua, J. H., \& Steier, L. (2005). Sources and consequences of distinctive familiness: An introduction. Entrepreneurship: Theory \& Practice, 29(3), 237-247.

Claver, E., Rienda, L., \& Quer, D. (2008). Family firms' risk perception: Empirical evidence on the internationalization process. Journal of small business and enterprise development, 15(3), 457-471.

De Massis, A., Chua, J. H., \& Chrisman, J. J. (2008). Factors preventing intra-family succession. Family Business Review, 21(2), 183-199.

Diwisch, D., Voithofer, P., \& Weiss, C. (2009). Succession and firm growth: Results from a non-parametric matching approach. Small Business Economics, 32(1), 45-56.

Dunn, B. (1999). The family factor: The impact of family relationship dynamics on businessowning families during transitions. Family Business Review, 12(1), 41-57.

Eddleston, K. A., \& Kellermanns, F. W. (2007). Destructive and productive family relationships: A stewardship theory perspective. Journal of Business Venturing, 22(4), 545-565.

Eddleston, K. A., Kellermanns, F. W., \& Sarathy, R. (2008). Resource configuration in family firms: Linking resources, strategic planning and technological opportunities to performance. Journal of Management Studies, 45(1), 26-50. 
European Commission (2006). Markets for business transfers fostering transparent marketplaces for the transfer of businesses in Europe. Brussels: European Commission Enteprise and Industry Directorate General.

Feltham, T. S., Feltham, G., \& Barnett, J. J. (2005). The dependence of family businesses on a single decision-maker. Journal of Small Business Management, 43(1), 1-15.

Gallo, M. A., Tapies, J., \& Cappuyns, K. (2004). Comparison of family and nonfamily business: Financial logic and personal preferences. Family Business Review, 17(4), 303-318.

Gómez-Mejía, L. R., Haynes, K. T., Núñez-Nickel, M., Jacobson, K. J. L., \& Moyano-Fuentes, J. (2007). Socioemotional wealth and business risks in family-controlled firms: Evidence from Spanish olive oil mills. Administrative Science Quarterly, 52(1), 106137.

Gómez-Mejía, L. R., Núñez-Nickel, M., \& Gutierrez, I. (2001). The role of family ties in agency contracts. Academy of Management Journal, 44(1), 81-95.

Grichnik, D., Koropp, C., \& Kellermanns, F. W. Financial choices in family firms: The influence of family norms. Annual Meeting of the Academy of Management (AOM) San Antonio, Texas (USA), 2011.

Habbershon, T. G., Williams, M., \& MacMillan, I. C. (2003). A unified systems perspective of family firm performance. Journal of Business Venturing, 18(4), 451-465.

Hair, J. F., Anderson, R. E., Tatham, R. L., \& Black, W. C. (1998). Multivariate data analysis with readings (5th ed.). Englewood Cliffs, NJ: Prentice-Hall.

Haynes, G., Walker, R., Rowe, B., \& Hong, G.-S. (1999). The intermingling of business and family finances in family-owned businesses. Family Business Review, 12(3), 225-239.

Heck, R. K. Z. (2004). A commentary on "entrepreneurship in family vs. Non-family firms: A resource-based analysis of the effect of organizational culture". Entrepreneurship: Theory \& Practice, 28(4), 383-389.

Hosmer, D. W., \& Lemeshow, S. (1989). Applied logistic regression. New York, NJ: John Wiley $\&$ Sons.

Ibrahim, A. B., Soufani, K., \& Lam, J. (2001). A study of succession in a family firm. Family Business Review, 14(3), 245-258.

Jensen, M. C., \& Meckling, W. H. (1992). Specific and general knowledge, and organizational structure. In L. Werin, \& H. Wijkander (Eds.), Contract economics (pp. 251-274). Malden, MA: Blackwell Publishing.

Johnson, E. (1988). Expertise and decision under uncertainty. In M. Chi, R. Glaser, \& M. Farr (Eds.), The nature of expertise (pp. 209-228). Hillsdale, NJ: Lawrence Erlbaum Associates.

Jones, C. D., Makri, M., \& Gomez-Mejia, L. R. (2008). Affiliate directors and perceived risk bearing in publicly traded, family-controlled firms: The case of diversification. Entrepreneurship: Theory \& Practice, 32(6), 1007-1026.

Kanuk, L., \& Berenson, C. (1975). Mail surveys and response rate: A literature review. Journal of Marketing Research, 22(4), 440-453.

Kaye, K., \& Hamilton, S. (2004). Roles of trust in consulting to financial families. Family Business Review, 17(2), 151-163.

Kimhi, A. (1997). Intergenerational succession in small family businesses: Borrowing constraints and optimal timing of succession. Small Business Economics, 9(4), 309318.

Klein, S. B., Astrachan, J. H., \& Smyrnios, K. X. (2005). The f-pec scale of family influence: Construction, validation, and further implication for theory. Entrepreneurship: Theory \& Practice, 29(3), 321-339.

L-Bank (2006). Generationenwechsel in Baden-Württemberg. Stuttgart. 
Lansberg, I. (1988). The succession conspiracy. Family Business Review, 1(2), 119-143.

Lansberg, I. (1999). Succeeding generations: Realizing the dream of families in business. Boston, MA: Harvard Business School Press.

Le Breton-Miller, I., Miller, D., \& Steier, L. P. (2004). Toward an integrative model of effective FOB succession. Entrepreneurship: Theory \& Practice, 28(4), 305-328.

Leonard, D., \& Sensiper, S. (1998). The role of tacit knowledge in group innovation. California Management Review, 40(3), 112-132.

López-Gracia, J., \& Sánchez-Andújar, S. (2007). Financial structure of the family business: Evidence from a group of small Spanish firms. Family Business Review, 20(4), 269287.

Lusardi, A., \& Mitchell, O. S. (2008). Planning and financial literacy: How do women fare? American Economic Review, 98(2), 413-417.

Lusardi, A., \& Tufano, P. (2009). Debt literacy, financial experiences, and overindebtedness. NBER Working Paper No. 14808.

March, J. G., \& Simon, H. A. (1958). Organizations. New York, NJ: John Wiley and Sons.

McConaughy, D. L., Matthews, C. H., \& Fialko, A. S. (2001). Founding family controlled firms: Performance, risk, and value. Journal of Small Business Management, 39(1), 31-49.

Michaelas, N., Chittenden, F., \& Poutziouris, P. (1998). A model of capital structure decision making in small firms. Journal of small business and enterprise development, 5(3), 246-260.

Miller, D. (1993). Some organizational consequences of CEO succession. Academy of Management Journal, 36(3), 644-659.

Miller, D., Steier, L., \& Le Breton-Miller, I. (2003). Lost in time: Intergenerational succession, change, and failure in family business. Journal of Business Venturing, 18(4), 513-531.

Mishra, C. S., \& McConaughy, D. L. (1999). Founding family control and capital structure: The risk of loss of control and the aversion to debt. Entrepreneurship: Theory \& Practice, 23(4), 53-64.

Mizruchi, M. S., \& Brewster Stearns, L. (1994). A longitudinal study of borrowing by large American corporations. Administrative Science Quarterly, 39(1), 118-140.

Modigliani, F., \& Miller, M. H. (1963). Corporate income taxes and the cost of capital: A correction. American Economic Review, 53(3), 433-443.

Moorman, C., Diehl, K., Brinberg, D., \& Kidwell, B. (2004). Subjective knowledge, search locations, and consumer choice. Journal of Consumer Research, 31(3), 673-680.

Morris, M. H., Williams, R. W., \& Nel, D. (1996). Factors influencing family business succession. International Journal of Entrepreneurial Behaviour \& Research, 2(3), 6881.

Mullins, J. W., \& Forlani, D. (2005). Missing the boat or sinking the boat: A study of new venture decision making. Journal of Business Venturing, 20(1), 47-69.

Myers, S. C. (1984). The capital structure puzzle. Journal of Finance, 39(3), 575-592.

Nunally, J. C. (1978). Psychometric theory (2nd ed.). New York, NJ: McGraw-Hill.

Parsons, C., \& Titman, S. (2008). Empirical capital structure: A review. Foundations \& Trends in Finance, 3(1), 1-93.

Pearson, A. W., Carr, J. C., \& Shaw, J. C. (2008). Toward a theory of familiness: A social capital perspective. Entrepreneurship: Theory \& Practice, 32(6), 949-969.

Pieper, T. M., Klein, S. B., \& Jaskiewicz, P. (2008). The impact of goal alignment on board existence and top management team composition: Evidence from family-influenced businesses. Journal of Small Business Management, 46(3), 372-394. 
Podsakoff, P. M., MacKenzie, S. B., Jeong-Yeon, L., \& Podsakoff, N. P. (2003). Common method biases in behavioral research: A critical review of the literature and recommended remedies. Journal of Applied Psychology, 88(5), 879-903.

Quinones, M. A., Ford, J. K., \& Teachout, M. S. (1995). The relationship between work experience and job performance: A conceptual and meta-analytic review. [Article]. Personnel Psychology, 48(4), 887-910.

Riding, A., Riding, A., Orser, B., Spence, M., \& Belanger, B. (2012). Financing new venture exporters. Small Business Economics, 38(2), 147-163.

Romano, C. A., Tanewski, G. A., \& Smyrnios, K. X. (2001). Capital structure decision making: A model for family business. Journal of Business Venturing, 16(3), 285-310.

Schneider, S. L., \& Lopes, L. L. (1986). Reflection in preferences under risk: Who and when may suggest why. Journal of Experimental Psychology: Human Perception and Performance, 12(4), 535-548.

Schulze, W. S., Lubatkin, M. H., \& Dino, R. N. (2003). Exploring the agency consequences of ownership dispersion among the directors of private family firms. Academy of Management Journal, 46(2), 179-194.

Seghers, A., Manigart, S., \& Vanacker, T. (2012). The impact of human and social capital on entrepreneurs' knowledge of finance alternatives. Journal of Small Business Management, 50(1), 63-86.

Sharma, P., Chrisman, J. J., \& Chua, J. H. (2003a). Predictors of satisfaction with the succession process in family firms. Journal of Business Venturing, 18(5), 667-687.

Sharma, P., Chrisman, J. J., \& Chua, J. H. (2003b). Succession planning as planned behavior: Some empirical results. Family Business Review, 16(1), 1-15.

Sharma, P., Chua, J. H., \& Chrisman, J. J. (2000). Perceptions about the extent of succession planning in Canadian family firms. Canadian Journal of Administrative Sciences, 17(3), 233-244.

Sharma, P., \& Irving, P. G. (2005). Four bases of family business successor commitment: Antecedents and consequences. Entrepreneurship: Theory \& Practice, 29(1), 13-33.

Shepherd, D. A., Zacharakis, A., \& Baron, R. A. (2003). VCs' decision processes: Evidence suggesting more experience may not always be better. Journal of Business Venturing, 18(3), 381-401.

Shin, H. S. (2009). Symposium: Early stages of the credit crunch: Reflections on northern rock: The bank run that heralded the global financial crisis. Journal of Economic Perspectives, 23(1), 101-119.

Simon, H. A. (1987). Making management decisions: The role of intuition and emotion. Academy of Management Executive, 1(1), 57-64.

Sitkin, S. B., \& Pablo, A. L. (1992). Reconceptualizing the determinants of risk behavior. Academy of Management Review, 17(1), 9-38.

Sitkin, S. B., \& Weingart, L. R. (1995). Determinants of risky decision-making behavior: A test of the mediating role of risk perceptions and propensity. Academy of Management Journal, 38(6), 1573-1592.

Smyrnios, K., Tanewski, G., \& Romano, C. (1998). Development of a measure of the characteristics of family business. Family Business Review, 11(1), 49-60.

Stavrou, E. T. (2003). Leadership succession in owner-managed firms through the lens of extraversion. International Small Business Journal, 21(3), 331-347.

Stiglitz, J. E., \& Weiss, A. (1981). Credit rationing in markets with imperfect information. American Economic Review, 71(3), 393-410.

Tourangeau, R., Rips, L. J., \& Rasinski, K. (2000). The psychology of survey response. Cambridge (UK): Cambridge University Press. 
Tversky, A., \& Kahneman, D. (1974). Judgment under uncertainty: Heuristics and biases. Science, 185(4157), 1124-1131.

Ucbasaran, D., Lockett, A., Wright, M., \& Westhead, P. (2003). Entrepreneurial founder teams: Factors associated with member entry and exit. Entrepreneurship: Theory \& Practice, 28(2), 107-127.

Van Auken, H. E. (2001). Financing small technology-based companies: The relationship between familiarity with capital and ability to price and negotiate investment. Journal of Small Business Management, 39(3), 240-258.

Williamson, O. E. (1988). Corporate finance and corporate governance. Journal of Finance, 43(3), 567-591. 


\section{Figures and Tables}

Figure 1: Conceptual Model of Succession Financing

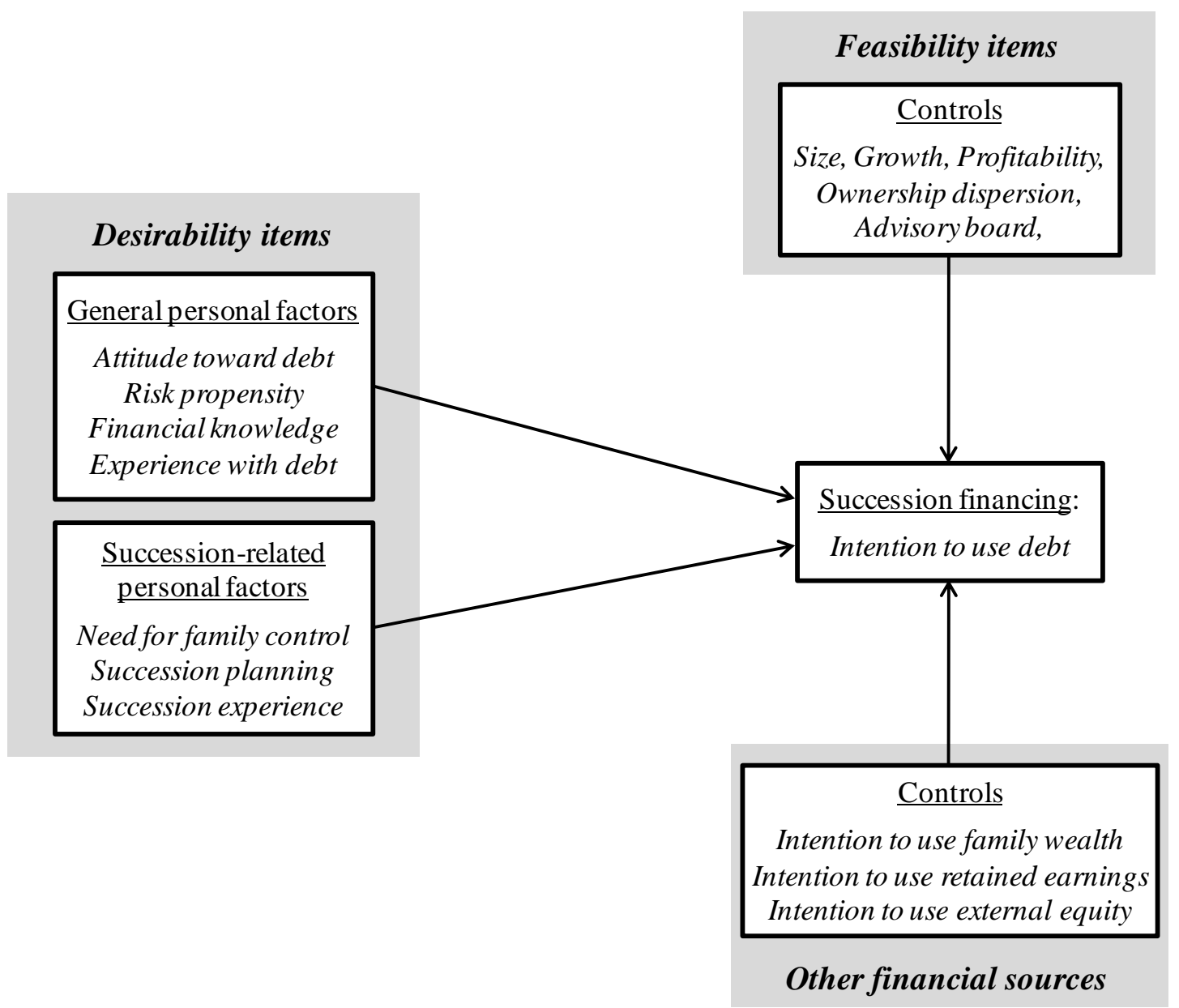


Table 1: Descriptive Statistics and Pearson Correlation Matrix

\begin{tabular}{|c|c|c|c|c|c|c|c|c|c|c|c|c|c|c|c|c|c|c|}
\hline & & Mean & SD & (1) & (2) & (3) & (4) & (5) & (6) & (7) & (8) & (9) & (10) & (11) & (12) & (13) & (14) & (15) \\
\hline (1) & Debt use intention $^{1}$ & 0.34 & 0.47 & & & & & & & & & & & & & & & \\
\hline (2) & Attitude & 4.25 & 1.54 & $0.26 * *$ & & & & & & & & & & & & & & \\
\hline (3) & Risk propensity & 1.10 & 1.31 & 0.08 & 0.08 & & & & & & & & & & & & & \\
\hline (4) & Financial knowledge & 2.38 & 1.43 & $0.22 * *$ & $0.20 * *$ & 0.07 & & & & & & & & & & & & \\
\hline (5) & Experience with debt & 4.56 & 1.53 & 0.12 & $0.28 * *$ & -0.01 & 0.00 & & & & & & & & & & & \\
\hline (6) & Need for family control & 4.08 & 1.47 & $-0.17 *$ & -0.09 & -0.10 & -0.08 & 0.03 & & & & & & & & & & \\
\hline (7) & Succession experience ${ }^{2}$ & 0.77 & 0.54 & $-0.26 * *$ & 0.00 & -0.05 & 0.06 & -0.04 & 0.03 & & & & & & & & & \\
\hline (8) & Succession planning ${ }^{1}$ & 0.69 & 0.46 & 0.04 & 0.02 & 0.06 & -0.02 & 0.06 & $0.15 *$ & -0.05 & & & & & & & & \\
\hline (9) & Size $^{2}$ & 16.26 & 1.33 & 0.01 & $0.22 * *$ & -0.04 & -0.01 & $0.22 * *$ & $-0.15 *$ & $0.16 *$ & $0.18 *$ & & & & & & & \\
\hline (10) & Growth & 9.24 & 15.71 & $0.21 * *$ & 0.05 & 0.02 & 0.04 & 0.13 & 0.02 & -0.13 & -0.13 & 0.02 & & & & & & \\
\hline (11) & Profitability & 15.29 & 35.18 & -0.09 & -0.13 & 0.04 & -0.03 & -0.10 & 0.01 & $-0.15 *$ & -0.11 & -0.10 & 0.05 & & & & & \\
\hline (12) & Ownership dispersion & 2.64 & 1.89 & -0.12 & -0.08 & -0.08 & 0.01 & 0.02 & 0.04 & $0.16 *$ & -0.01 & $0.29^{* *}$ & 0.06 & -0.04 & & & & \\
\hline (13) & Advisory board $^{1}$ & 0.12 & 0.33 & 0.01 & $0.15 *$ & 0.05 & 0.11 & -0.01 & -0.07 & $0.16 *$ & -0.07 & $0.15 *$ & -0.02 & -0.05 & $0.38 * *$ & & & \\
\hline (14) & Intention to use family wealth ${ }^{1}$ & 0.49 & 0.50 & 0.08 & -0.04 & -0.07 & 0.10 & 0.02 & $-0.16 *$ & 0.03 & -0.04 & 0.01 & 0.08 & 0.02 & 0.03 & -0.07 & & \\
\hline (15) & Intention to use retained earnings ${ }^{1}$ & 0.68 & 0.47 & $-0.32 * *$ & -0.07 & 0.00 & -0.08 & 0.12 & $0.20 * *$ & 0.14 & 0.14 & $0.20 * *$ & 0.00 & 0.02 & 0.09 & 0.04 & $-0.21 * *$ & \\
\hline (16) & Intention to use external equity ${ }^{1}$ & 0.05 & 0.22 & $0.16 *$ & 0.07 & -0.04 & 0.06 & -0.08 & -0.12 & -0.06 & -0.07 & 0.03 & -0.07 & -0.02 & -0.02 & -0.01 & -0.02 & -0.06 \\
\hline
\end{tabular}

$\mathrm{n}=187$; Significance level: $+\mathrm{p}<0.10,{ }^{*} \mathrm{p}<0.05,{ }^{* *} \mathrm{p}<0.01$ (two-tailed); ${ }^{1}$ Dummy-coded variable, ${ }^{2}$ Logarithmized 
Table 2: Logistic Regression Models of Variables Associated with the Intention to Finance Succession with Debt

\begin{tabular}{|c|c|c|c|c|c|c|c|c|c|c|c|c|c|c|c|}
\hline & \multicolumn{3}{|c|}{ Model 1} & \multicolumn{3}{|c|}{ Model 2} & \multicolumn{3}{|c|}{ Model 3} & \multicolumn{3}{|c|}{ Model 4} & \multicolumn{3}{|c|}{ Model 5} \\
\hline & $\mathrm{B}$ & SE & Odds & $\mathrm{B}$ & $\mathrm{SE}$ & Odds & $\mathrm{B}$ & SE & Odds & $\mathrm{B}$ & SE & Odds & $\mathrm{B}$ & $\mathrm{SE}$ & Odds \\
\hline \multicolumn{16}{|l|}{ Independent variables } \\
\hline Attitude toward debt & & & & $0.226 \dagger$ & 0.136 & 1.254 & $0.275 \dagger$ & 0.150 & 1.317 & $0.543 *$ & 0.261 & 1.721 & 0.224 & 0.204 & 1.320 \\
\hline Risk propensity & & & & 0.137 & 0.139 & 1.146 & 0.123 & 0.150 & 1.131 & 0.184 & 0.248 & 1.202 & 0.214 & 0.221 & 1.233 \\
\hline Financial knowledge & & & & $0.346 *$ & 0.138 & 1.413 & $0.414 * *$ & 0.149 & 1.514 & 0.333 & 0.287 & 1.394 & $0.573 * *$ & 0.209 & 1.691 \\
\hline Positive experience with debt & & & & $0.228 \dagger$ & 0.133 & 1.255 & 0.226 & 0.144 & -1.253 & $0.455 \dagger$ & 0.245 & 1.576 & 0.038 & 0.211 & 1.049 \\
\hline Need for family control & & & & & & & -0.223 & 0.146 & 0.800 & -0.230 & 0.250 & 0.795 & -0.206 & 0.223 & 0.791 \\
\hline Succession experience & & & & & & & $-1.293 * *$ & 0.431 & 0.275 & $-1.388 *$ & 0.695 & 0.250 & $-1.266 \dagger$ & 0.678 & 0.235 \\
\hline Succession planning & & & & & & & $1.069 *$ & 0.499 & 2.914 & 1.855 & 1.379 & 6.390 & 0.991 & 0.641 & 2.339 \\
\hline \multicolumn{16}{|l|}{ Controls } \\
\hline Profitability & -0.015 & 0.011 & 0.985 & -0.019 & 0.013 & 0.981 & $-0.023 *$ & 0.010 & 0.977 & -0.083 & 0.039 & 0.962 & 0.016 & 0.018 & 1.345 \\
\hline Size & $0.259 \dagger$ & 0.149 & 1.296 & 0.183 & 0.159 & 1.201 & 0.195 & 0.176 & 0.122 & -0.035 & 0.328 & 0.965 & $0.443 \dagger$ & 0.249 & 1.057 \\
\hline Growth & $0.047 * *$ & 0.014 & 1.048 & $0.049 * *$ & 0.015 & 1.050 & $0.051 * *$ & 0.015 & 1.052 & 0.021 & 0.030 & 1.021 & $0.072 * *$ & 0.024 & 1.008 \\
\hline Advisory board & 0.458 & 0.549 & 1.581 & 0.149 & 0.580 & 1.160 & 0.403 & 0.650 & 1.496 & 1.581 & 1.623 & 4.859 & -0.269 & 0.829 & 0.825 \\
\hline Ownership dispersion & $-0.272 *$ & 0.128 & 0.762 & $-0.239 \dagger$ & 0.133 & 0.787 & $-0.257 \dagger$ & 0.145 & 0.774 & -0.210 & 0.307 & 0.811 & -0.249 & 0.208 & 0.794 \\
\hline Intention to use family wealth & 0.035 & 0.366 & 1.036 & 0.082 & 0.392 & 1.086 & 0.165 & 0.430 & 1.179 & $1.239 \dagger$ & 0.744 & 3.451 & -0.770 & 0.668 & 0.235 \\
\hline Intention to use retained earnings & $-1.692 * * *$ & 0.400 & 0.184 & $-1.819 * * *$ & 0.434 & 0.162 & $-1.757 * * *$ & 0.464 & 0.173 & $-1.706 *$ & 0.892 & 0.182 & $-2.335 * *$ & 0.686 & 2.339 \\
\hline Intention to use external equity & $1.724 *$ & 0.781 & 5.605 & $1.965 *$ & 0.847 & 7.136 & $1.926 *$ & 0.883 & 6.864 & 2.621 & 1.748 & 13.750 & 1.318 & 1.229 & 0.235 \\
\hline Model $\chi^{2}$ & $42.965 * * *$ & & & $60.078 * * *$ & & & $79.568 * * *$ & & & $38.147 * *$ & & & $52.174 * * *$ & & \\
\hline$\Delta \chi^{2}$ & & & & $17.113 * *$ & & & $19.490 * *$ & & & & & & & & \\
\hline Hosmer \& Lemeshow test (p value) & 0.19 & & & 0.29 & & & 0.67 & & & 0.74 & & & 0.44 & & \\
\hline Overall predictive accuracy & $74.9 \%$ & & & $76.5 \%$ & & & $78.6 \%$ & & & $80.7 \%$ & & & $79.8 \%$ & & \\
\hline Nagelkerkes $\mathrm{R}^{2}$ & 0.285 & & & 0.381 & & & 0.466 & & & 0.514 & & & 0.544 & & \\
\hline$\Delta \mathrm{R}^{2}$ & & & & 0.096 & & & 0.085 & & & & & & & & \\
\hline $\mathrm{n}$ & 187 & & & 187 & & & 187 & & & 83 & & & 104 & & \\
\hline
\end{tabular}

Significance level: $\dagger \mathrm{p}<0.10, * \mathrm{p}<0.05, * * \mathrm{p}<0.01, * * * \mathrm{p}<0.001$ (two-tailed) 


\section{University Library}

\section{- M M I E R R A A gateway to Melbourne's research publications}

Minerva Access is the Institutional Repository of The University of Melbourne

Author/s:

Koropp, C;Grichnik, D;Gygax, AF

Title:

Succession financing in family firms

Date:

2013-08-01

Citation:

Koropp, C., Grichnik, D. \& Gygax, A. F. (2013). Succession financing in family firms. SMALL BUSINESS ECONOMICS, 41 (2), pp.315-334. https://doi.org/10.1007/s11187-012-9442-z.

Persistent Link:

http://hdl.handle.net/11343/282674 